\title{
Association between Accessory Nipple and Coronary Artery Disease
}

\author{
Dr Prabhu C Halkati¹, Dr Suresh V Patted ${ }^{2}$, Dr Vishwanath Hesarur ${ }^{3}$, Dr Sanjay C Porwal ${ }^{4}$, \\ Dr Sameer Ambar ${ }^{5}$, Dr Ameet Sattur ${ }^{6}$
}

\begin{abstract}
Introduction: Accessory nipples (AN) are associated with renal anomaly, hematologic disorders, and cardiovascular disorders with Congenital heart disease, conduction system abnormalities, systemic hypertension and Mitral valve prolapse. There is no data and literature regarding association of $A N$ with coronary artery disease (CAD) and not yet been investigated, hence the present study was undertaken. Aim and Objective: The purpose of this study was to know the association of AN with CAD. Materials And Methods: A case control study was conducted at KLE's Dr. Prabhakar Kore Hospital \& MRC, Belgaum, Karnataka, India, between January 2013 to September 2015. A total of 84 patients with AN and unstable angina, chronic stable angina and recent or prior myocardial infarction (MI) and 55 age and sex matched healthy controls were evaluated for evidence of CAD. Detailed baseline clinical, electrocardiography (ECG), echocardiography (ECHO) and coronary angiography (CAG) data were collected and compared among cases and controls. Results: A total of 139 patients were evaluated (84 cases,55 controls). Majority of the patients were male (89.29\% vs 92.73\%) and in the age group of 51-60 years. Cases had a higher incidence of dyslipidemia (72.62\% vs 56.36\%;p=0.049), cerebral vascular accidents $(8.33 \%$ vs $0.00 \%$; $=0.006)$, prior MI $(26.19 \%$ vs $0.00 \% ; p=0.000)$ and prior PCI (5.95\% vs $0.00 ; p=0.021 \%)$ compared to control group. Cases had higher incidence of abnormal ECG's and ECHO findings compared to control group (p=0.000). CAG revealed higher incidence of coronary lesions among cases \{single vessel disease(54.22\%),double vessel disease(27.71\%) and triple vessel disease(18.07\%)\}and normal coronaries among control group ( $p=0.000)$. Conclusion: The study detected a positive association between accessory nipple and coronary artery disease. So, accessory nipples should be always considered during routine physical and cardiovascular examination and require appropriate cardiac investigation for screening of associated congenital and acquired cardiac disorders.
\end{abstract}

Keywords: Accessory nipples (AN), Coronary artery disease (CAD), Myocardial infarction (MI), Coronary angiography (CAG), Hypertension (HTN).

\section{Introduction}

Accessory nipples (AN) or Supernumerary nipples are common minor congenital malformations that consist of nipples and/or related tissue in addition to the nipples normally appearing on the chest. Polymastia refers to accessory breast tissue in addition to normal breast tissue. This occurs in $2-6 \%$ of females and $1-3 \%$ males. ${ }^{1}$

AN are commonly located along the embryonic milk line which extends bilaterally from the axilla through the normal nipple in the chest and the abdomen towards the groin.(Figure 1)
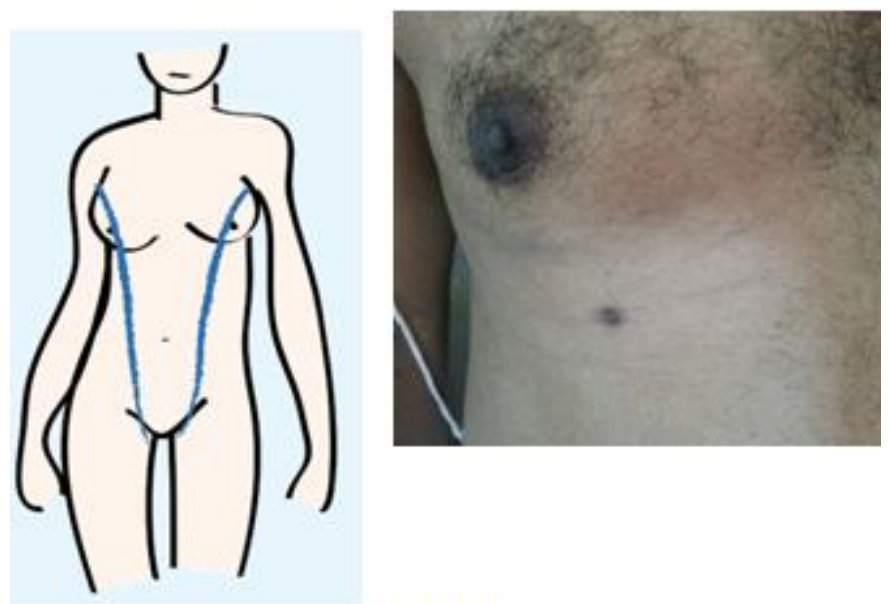

Figure 1 (a)

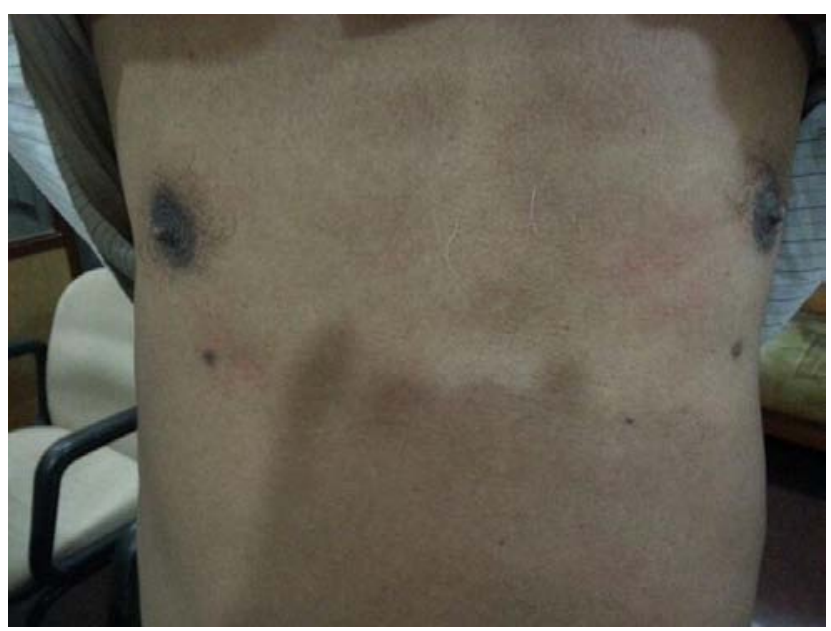

Figure 1 (b)

Figure 1: Embryonic Milk line, 1(a) Accessory nippleunilateral, 1(b) Accessory nipple -bilateral.

Most AN are located inferior and medial to normal nipple, while approximately $13 \%$ appear above it along the milk line. ${ }^{2}$ In $5 \%$ of patients, they are ectopic located outside the milk line such as on back ${ }^{3}$, shoulder ${ }^{4}$, neck, face, legs and spine. They may be mistaken for a birth mark, mole, neurofibroma, papilloma or nevus. In $75 \%$ of patients, it measures no more than $30 \%$ of the diameter of the normal nipple $(0.2-0.3 \mathrm{~cm})$. In other $25 \%$ of patients, it is as large as $50 \%$ of the normal size of the nipple. Rarely, a AN is as large as a normal nipple. ${ }^{5}$ Most of these patients are asymptomatic until puberty when they enlarge and lactate due to hormonal stimulation.

AN are found is association with other diseases. Several studies have reported the association of accessory nipples 


\section{International Journal of Science and Research (IJSR) \\ ISSN (Online): 2319-7064 \\ Index Copernicus Value (2013): 6.14 | Impact Factor (2014): 5.611}

with renal anomaly ${ }^{6-9}$, hematologic disorders ${ }^{10}$, epibulbar lipodermoids associated with preauricular appendages syndrome ${ }^{11}$ and cardiovascular disorders with Congenital heart disease 12,13, conduction system abnormalities 14,15, systemic hypertension ${ }^{12}$ and Mitral valve prolapse. ${ }^{16}$ There in no data and literature regarding association of accessory nipple with coronary artery disease (CAD) and not yet been investigated, hence the present study was undertaken .

\section{Material \& Methods}

Study design - A case control study was conducted at KLE's Dr. Prabhakar Kore Hospital \& MRC, Belgaum , Karnataka, India, between January 2013 to September 2015. A total of 84 patients with accessory nipple and with unstable angina, chronic stable angina and history of recent or prior myocardial infarction (Myocardial infarction) and 55 age and sex matched healthy controls were evaluated for evidence of CAD. The study was approved by the institutional ethics committee.

Patients with unstable angina, chronic stable angina and history of recent or prior myocardial infarction (Myocardial infarction) were included in the study.

\section{Definitions of risk factors and diagnostic criteria:}

Hypertension - Patients were considered as hypertensive when the BP recorded on the day of admission was SBP $\geq$ $140 \mathrm{~mm} \mathrm{Hg}$ and /or $\mathrm{DBP} \geq 90 \mathrm{~mm} \mathrm{hg}$ or on antihypertensives. Dyslipidemia - was defined according to NCEP ATP III Guidelines. ${ }^{17}$ Diabetic when FBS $>126 \mathrm{mg} / \mathrm{dl}$ or $\mathrm{Hb}$ a $1 \mathrm{c}>6.5 \%$ or on medication for Diabetes. Obesity when Body mass index (BMI) $\geq 30 \mathrm{Kg} / \mathrm{m} 2$. Smoker current regular use ( any amount ) or cigarette withdrawal $<$ 2 months. Alcoholic - Alcohol intake $>40$ gm/day. Family history of Coronary artery disease (CAD) - A Positive family history is defined as a parent, grandparent, aunt, uncle and / or sibling with history of treated angina, MI, percutaneous coronary catheter interventional procedure, Coronary artery bypass surgery (CABG), stroke or sudden cardiac death before 55 yrs in men or $65 \mathrm{yrs}$ women. ${ }^{18}$ Peripheral vascular disease (PVD) - History of claudication pain in the lower limbs confirmed by clinical examination and colour doppler study. Cerebral vascular accident (CVA) - History of prior stroke with or without residual deficit and confirmed by neurologist.

All patients detailed clinical history, physical Examination, Electrocardiography (ECG) and Echocardiography (ECHO) finding were recorded and entered in pretested proforma. All patients underwent coronary angiography (CAG) and were classified as Normal epicardial coronaries ( No lesions detected ), minor lesions ( $<50 \%$ occlusion), and single vessel ( SVD) (>50\% occlusion ), Double vessel (DVD) and triple vessel disease (TVD). Presence of AN were defined according to Kajava Y. ${ }^{(19)}$
Statistical analysis: Chi-square test of association, proportion test, Two sample t-test for equal variances were used for finding association between various cardiovascular risk factors and selected demographic variables. All statistical calculations were performed with SPSS version 17 statistical software. A p value of 0.05 or less was considered significant.

\section{Results}

Between January 2013 to September 2015, a total of 84 patients with AN and 55 age and sex matched healthy controls were evaluated. $60.43 \%(84)$ of the patients were found with CAD while $39.57 \%$ (55) of the patients without CAD. (Figure 2)

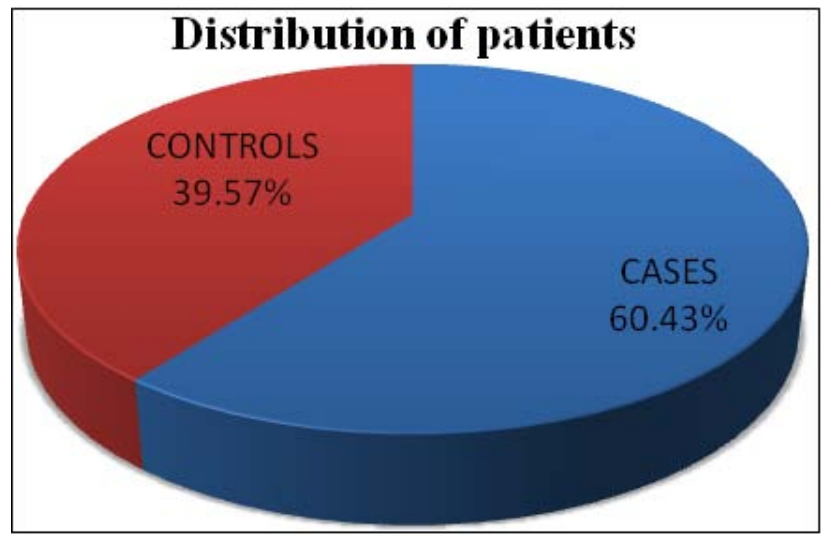

Figure 2: Distribution of Patients

There were 75 males and 9 females in cases and 51 males and 4 females in the control group. Majority of patients were in the age group of 51-60yrs in both groups.(Table $1 \&$ Table 2)

Table 1: Sex Distribution

\begin{tabular}{|c|c|c|c|c|c|}
\hline \multirow{2}{*}{ Sex } & \multicolumn{2}{|c|}{ Cases $(n=84)$} & \multicolumn{2}{|c|}{ Controls $(n=55)$} & \multirow{2}{*}{ P Value } \\
\cline { 2 - 5 } & Frequency & Percentage & Frequency & Percentage & \\
\hline Male & 75 & $59.52 \%$ & 51 & $40.48 \%$ & \multirow{2}{*}{$0.496^{\mathrm{NS}}$} \\
\hline Female & 9 & $69.23 \%$ & 4 & $30.77 \%$ & \\
\hline
\end{tabular}

Chi-sq Test of Association, NS: Not Significant

Table 2: Age Distribution

\begin{tabular}{|c|c|c|c|c|c|}
\hline \multirow{2}{*}{$\begin{array}{c}\text { Age } \\
\text { Years })\end{array}$} & \multicolumn{2}{|c|}{ Cases $(n=84)$} & \multicolumn{2}{|c|}{ Controls $(n=55)$} & \multirow{2}{*}{ P Value } \\
\cline { 2 - 5 } & Frequency & Percentage & Frequency & Percentage & \\
\hline 440 & 7 & $38.89 \%$ & 11 & $61.11 \%$ & \\
\hline $51-50$ & 19 & $55.88 \%$ & 15 & $44.12 \%$ & \multirow{2}{*}{$0.065^{\mathrm{NS}}$} \\
\hline$>60$ & 37 & $61.67 \%$ & 23 & $38.33 \%$ & \\
\hline
\end{tabular}

Chi-sq Test of Association, NS: Not Significant

Cases had higher incidence of dyslipidemia, CVA, PVD, Prior MI (Myocardial infarction) and Prior PCI (Percutaneous coronary Intervention) than controls which was statistically significant. (Table 3 ) 


\section{International Journal of Science and Research (IJSR) \\ ISSN (Online): 2319-7064}

Index Copernicus Value (2013): 6.14 | Impact Factor (2014): 5.611

Table 3: Risk Factors for Coronary Artery Disease

\begin{tabular}{|c|c|c|c|c|c|}
\hline \multirow{2}{*}{ Variable } & \multicolumn{2}{|c|}{ Cases $(n=84)$} & \multicolumn{2}{c|}{ Controls $(n=55)$} & \multirow{2}{*}{ P Value } \\
\cline { 2 - 5 } & Frequency & Percentage & Frequency & Percentage & \\
\hline Diabetes & 52 & 61.90 & 26 & 47.27 & $0.088^{\mathrm{NS}}$ \\
\hline Hypertension & 51 & 60.71 & 32 & 58.18 & $0.766^{\mathrm{NS}}$ \\
\hline Dyslipidemia & 61 & 72.62 & 31 & 56.36 & $0.049^{*}$ \\
\hline Obesity & 28 & 33.33 & 20 & 36.36 & $0.714^{\mathrm{NS}}$ \\
\hline Smoking & 30 & 35.71 & 21 & 38.18 & $0.768^{\mathrm{NS}}$ \\
\hline Alcohol & 36 & 42.86 & 29 & 52.73 & $0.253^{\mathrm{NS}}$ \\
\hline Family History of CAD & 23 & 27.38 & 22 & 40.00 & $0.124^{\mathrm{NS}}$ \\
\hline CVA & 7 & 8.33 & 0 & 0.00 & $0.006^{* *}$ \\
\hline PVD & 23 & 27.38 & 22 & 40.00 & $0.124^{\mathrm{NS}}$ \\
\hline Prior MI & 22 & 26.19 & 0 & 0.00 & $0.000^{* *}$ \\
\hline Prior PCI & 5 & 5.95 & 0 & 0.00 & $0.021^{*}$ \\
\hline Prior CABG & 3 & 3.57 & 0 & 0.00 & $0.078^{\mathrm{NS}}$ \\
\hline
\end{tabular}

Proportion Test, NS: Not Significant, *: Significant, **: Highly Significant

Cases had higher incidence of abnormal ECG and Echocardiography findings at presentation compared to controls which was statistically significant. (Table 4 \& Table 5)

Table 4: ECG at Presentation

\begin{tabular}{|c|c|c|c|c|c|}
\hline \multirow{2}{*}{ ECG } & \multicolumn{2}{|c|}{ Cases $(\mathrm{n}=84)$} & \multicolumn{2}{c|}{ Controls $(\mathrm{n}=55)$} & P Value \\
\cline { 2 - 5 } & Frequency & Percentage & Frequency & Percentage & \\
\hline Normal & 37 & 44.05 & 44 & 80.00 & \\
\hline $\begin{array}{c}\text { ST-T } \\
\text { Changes }\end{array}$ & 16 & 19.05 & 11 & 20.00 & \multirow{2}{*}{$0.000^{* *}$} \\
\hline AWMI & 21 & 25.00 & 0 & 0.00 & \\
\hline IWMI & 10 & 11.90 & 0 & 0.00 & \\
\hline
\end{tabular}

Chi-sq Test of Association, **: Highly Significant
Table 5: Echocardiography at Presentation

\begin{tabular}{|c|c|c|c|c|c|}
\hline $\begin{array}{c}\text { Ejection } \\
\text { Fraction } \\
(\%)\end{array}$ & \multicolumn{2}{|c|}{ Cases $(\mathrm{n}=84)$} & \multicolumn{2}{c|}{ Controls $(\mathrm{n}=55)$} & \multirow{2}{*}{ P Value } \\
\cline { 2 - 5 } & Frequency & Percentage & Frequency & Percentage & \\
\hline $\begin{array}{c}\text { Normal } \\
(52-72)\end{array}$ & 43 & 51.19 & 54 & 98.18 & \\
\hline $\begin{array}{c}\text { Mild } \\
(41-51)\end{array}$ & 27 & 32.14 & 1 & 1.82 & \multirow{2}{*}{$0.000^{* *}$} \\
\hline $\begin{array}{c}\text { Moderate } \\
(30-40)\end{array}$ & 14 & 16.67 & 0 & 0 & \\
\hline $\begin{array}{c}\text { Severe } \\
(<30)\end{array}$ & 0 & 0 & 0 & 0 & \\
\hline
\end{tabular}

Chi-sq Test of Association, **: Highly Significant

AN was located predominantly on right side in $53.57 \%$ followed by left side $35.71 \%$ and bilateral in $10.71 \%$ patients.(Figure 3)

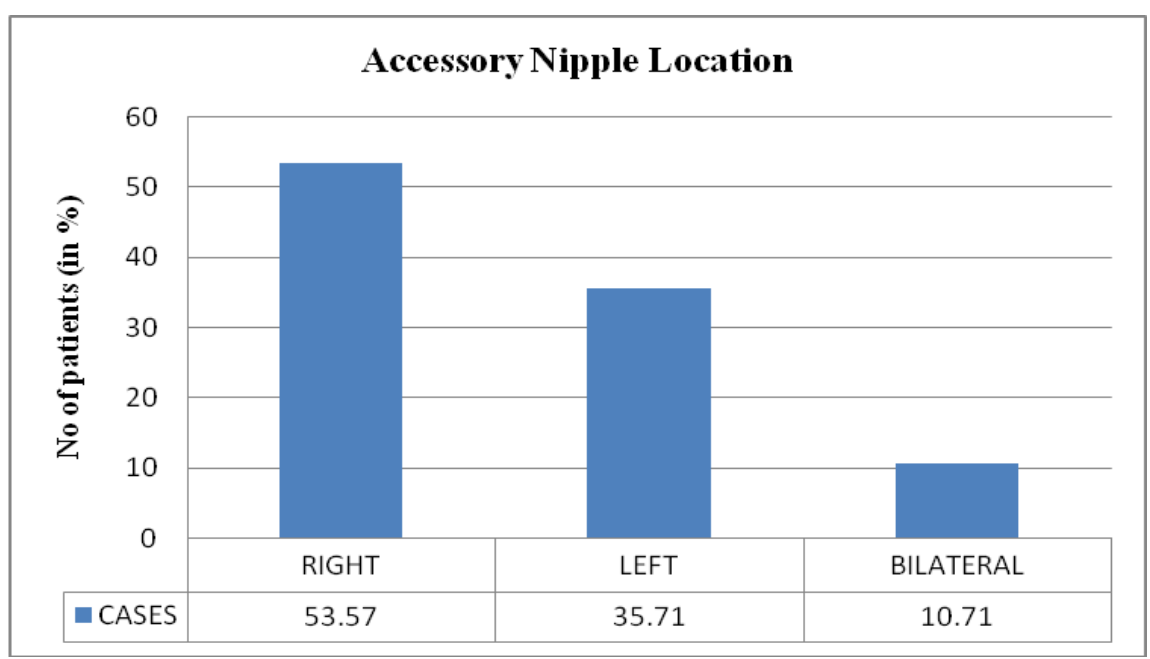

Figure 3: Accessory Nipple Location

CAG revealed higher incidence of coronary lesions among cases and normal epicardial coronaries among controls which was statistically significant .(Table 6)
Table 6: Coronary Angiography

\begin{tabular}{|c|c|c|c|c|c|}
\hline \multirow{2}{*}{ Variable } & \multicolumn{2}{|c|}{ Cases $(n=84)$} & \multicolumn{2}{|c|}{ Controls $(n=55)$} & \multirow{2}{*}{ P Value } \\
\cline { 2 - 5 } & Frequency & Percentage & Frequency & Percentage & \\
\hline NEC & 0 & 0.00 & 55 & 100.00 & \multirow{2}{*}{$0.000^{* *}$} \\
\hline SVD & 45 & 54.22 & 0 & 0.00 & \\
\hline DVD & 23 & 27.71 & 0 & 0.00 & \\
\hline
\end{tabular}

Chi-sq Test of Association, **: Highly Significant 


\section{International Journal of Science and Research (IJSR) \\ ISSN (Online): 2319-7064}

Index Copernicus Value (2013): 6.14 | Impact Factor (2014): 5.611

Among cases , $77.38 \%$ of patients underwent angioplasty with stenting, $16.67 \%$ underwent coronary artery bypass surgery $(\mathrm{CABG})$ and $5.95 \%$ were managed medically.(Table 7)

Table 7: Management

\begin{tabular}{|c|c|c|c|c|c|}
\hline Variable & \multicolumn{2}{|c|}{ Cases $(n=84)$} & \multicolumn{2}{c|}{ Controls $(n=55)$} & \multirow{2}{*}{ P Value } \\
\cline { 2 - 5 } & Frequency & Percentage & Frequency & Percentage & \\
\hline $\begin{array}{c}\text { PTCA with } \\
\text { Stenting }\end{array}$ & 65 & 77.38 & 0 & 0.00 & \multirow{2}{*}{$0.000^{* *}$} \\
\hline CABG & 14 & 16.67 & 0 & 0.00 & \\
\hline MLM & 5 & 5.95 & 55 & 100.00 & \\
\hline
\end{tabular}

Chi-sq Test of Association, **: Highly Significant

\section{Discussion}

AN (or) supernumerary ripples also known as polythetia are the most common form of accessory breast tissue malformation. These AN are located along the Embryonic milk line which Extends bilaterally from the axilla through the normal nipple in the chest and the abdomen towards the groin.

The Prevalence of AN varies geographically, $0.22 \%$ in Hungarian population ${ }^{11}, 1.63 \%$ in African American neonates $^{21}, 2.5 \%$ in Israeli neonates ${ }^{22} \& 5.6 \%$ in german children. ${ }^{23}$ Incidence is similar in males and females. Most cases are sporadic, but approximately $1 \%$ are familial and are believed to represent an autosomal dominant trait with variable penetrance. ${ }^{24,25}$

Between the $4^{\text {th }}$ and $5^{\text {th }}$ weeks of gestation, an ectodermal thickening forms symmetrically along the ventral lateral sides of the embryo. This epidermal ridge extends from the axillary region to the inner side of the thigh to form the embryogenic milk (or mammary) line. During the $2^{\text {nd }}$ and $3^{\text {rd }}$ months of fetal development, the glandular elements of the breast are formed near the $4^{\text {th }}$ and $5^{\text {th }}$ ribs, with regression of the rest of the thickened ectodermal streaks. In the case of failure of a complete regression, some foci may remain, resulting in a AN. This can develop into a accessory breast (polymastia) or into any other AN variant according to the Kajava classification. ${ }^{19}$

In 1959, Evans ${ }^{12}$ first reported the association of AN with cardiovascular disorders with systemic hypertension, cardiomyopathy due to MI and Congenital heart disease (CHD) with pulmonary hypertension (Atrial septal defect, Ventricular septal defect, Patent ductus arteriosus) in $35 \%$, $44 \%$ and $44 \%$ of patients respectively. Similarly, kramer et al. ${ }^{13}$ also found significant association of $\mathrm{CHD}$ with supernumerary ripples.

Studies conducted by Mate et al. ${ }^{14,25}$ \& Pellegrini et al. ${ }^{15}$ found higher incidence of conduction system abnormalities mainly bundle branch block and complete heart block. Mate et al. $^{25}$ reported a 10 fold increase in the incidence of Left bundle branch block (LBBB) in supernumerary nipple affected patients than controls.

Study conducted by Rajaratnam $\mathrm{K}$ et al. ${ }^{16}$ found higher incidence of AN with mitral valve prolapse in asian Indians. In our study, we found a higher incidence of coronary artery disease among cases than controls indicating an association of AN with CAD.

Study limitations: It was single centre study. Further investigations should be performed with larger studies to substantiate this finding.

\section{Conclusion}

The study detected a positive association between accessory nipple and coronary artery disease. So, accessory nipples should be always considered during routine physical and cardiovascular examination and require appropriate cardiac investigation for screening of associated congenital and acquired cardiac disorders.

\section{References}

[1] Kose R, Ozgoonul A, Bingol I Intra areolar Polythelia : A Rare Anamoly. J Pak Med Assoc.2012 May;62(5):499-500

[2] Mimouni F, Merlob P, Reisner SH. Occurrence of supernumerary nipples in newborns. Am J Dis Child. 1983 Oct. 137(10):952-3.

[3] Hanson E, Segovia J. Dorsal supernumerary breast. Case report. Plast Reconstr Surg. 1978 Mar. 61(3):441-5.

[4] Schewach-Millet M, Fisher BK. Supernumerary nipple on the shoulder. Cutis. 1976 Feb. 17(2):384-5._.

[5] Schmidt H. Supernumerary nipples: prevalence, size, sex and side predilection -- a prospective clinical study.Eur J Pediatr. 1998 Oct. 157(10):821-3. .

[6] Méhes K. Association of supernumerary nipples with other anomalies. J Pediatr 1983;102:161.

[7] Kahn SA, Wagner RF Jr. Polythelia and unilateral renal agenesis. Cutis 1982;30:225-6.

[8] Leung AK, Robson WL. Renal anomalies in familial polythelia. Am J Dis Child 1990;144:619-20.

[9] Urbani CE, Betti R. Accessory mammary tissue associated with congenital and hereditary nephronurinary malformations. Int J Dermatol 1996;35:349-52.

[10] Aslan D, Gürsel T, Kaya Z. Supernumerary nipples in children with hematologic disorders. Pediatr Hematol Oncol. 2004 Jul-Aug;21(5):461-3.

[11] Goldschmidt E, Jacobsen N. Epibulbar lipodermoids, preauricular appendages and polythelia in four generations: a new hereditary syndrome?. Ophthalmic Genet. 2010 Jun. 31(2):81-3.

[12] Evans W. Polythelia in cardio-arterial disease. $\mathrm{Br}$ Heart J 1959;21:130-6.

[13] Kramer HH, Majevski F, Trampisch HJ, Rammos S, Bourgeois M. Malformation patterns in children with congenital heart disease. Am J Dis Child 1987;141:789-95.

[14] Mate K, Horvath I, Schmidt J, Kulcsar M, Erdel M, Balint ZS, et al. Polythelia associated with disturbances of cardiac conduction. Cor Vasa 1979;21:112-6.

[15] Pellegrini JR, Wagner RF Jr. Polythelia and associated conditions. Am Fam Physician 1983;28:129-32.

[16] Rajaratnam K $\mathrm{K}^{1}$, Kumar PD, Sahasranam KV. Supernumerary nipple as a cutaneous marker of mitral

\section{Volume 4 Issue 11, November 2015}




\section{International Journal of Science and Research (IJSR) \\ ISSN (Online): 2319-7064}

Index Copernicus Value (2013): 6.14 | Impact Factor (2014): 5.611

valve prolapse in Asian Indians. Am J Cardiol. 2000

Sep 15;86(6):695-7, A9.

[17] Third report on national cholesterol education program (NCEP). Expert Panel on Detection,Evaluation, and Treatment of High Blood cholesterol in Adults (Adult Treatment Panel III),Executive summary.

[18] Expert Panel on Integrated Guidelines for Cardiovascular Health and Risk Reduction in Children and Adolescents: Summary Report. 2011.

[19] The proportions of supernumerary nipples in the Finnish population. Duodecim. 1915; 1:143-70. Reported in Lakkawar NJ, Maran G, Srinivasan S, Rangaswamy T. Accessory breast tissue in the axilla in a puerperal woman - case study. AMM. 2010;49(4):45-7.

[20] Smith DW. Comment on association of supernumerary nipples with other anomalies. Oska FA, Stockman JA III, eds. Year Book of Pediatrics. Chicago, Ill: YB Medical Publishers; 1981. 437.

[21] Rahbar F. Clinical significance of supernumerary nipples in black neonates. Clin Pediatr (Phila). 1982 Jan. 21(1):46-7. .

[22] Casey HD, Chasan PE, Chick LR. Familial polythelia without associated anomalies. Ann Plast Surg. 1996 Jan. 36(1):101-4. .

[23] Emily C Grimshaw BS, Philip R Cohen MD Supernumerary nipple and seminoma: Case report and review of polythelia and genitourinary cancers Dermatology Online Journal 19 (1): 4 January 2013.

[24] Assimina Galli Tsinopoulou , Carsten Krohn , Heinrich Schmidt. Familial Polythelia over 3 generations with Polymastia in the youngest girl. European journal of Pediatrics. May 2001, Vol 160, Issue 6, pp 375-377.

[25] Mate K. Association of polythelia and aberrant ventricular conduction. Orv Hetil 1976;117:2683

\section{Author Profile}

Dr Prabhu C Halkati MD,DM,FACC,FAPSIC,FCSI Professor, Department of Cardiology, J.N.Medical college, Belgaum , Karnataka, India-590001.

Dr Suresh V Patted MD, DM, FACC, FAPSIC, FCSI Professor and HOD, Department of Cardiology, J.N.Medical college, Belgaum, Karnataka, India-590001.

Dr Vishwanath Hesarur Senior Resident Department of Cardiology, J. N. Medical college, Belgaum, Karnataka, India590001.

Dr Sanjay C Porwal MD, DNB (cardiology), FAPSIC, FSCA, FACC Associate Professor, Department of Cardiology, J. N. Medical college, Belgaum, Karnataka,India-590001.

Dr Sameer Ambar MD,DM Associate Professor, Department of Cardiology, J. N. Medical college, Belgaum , Karnataka, India590001.

Dr Ameet Sattur MD,DM, Assistant Prof, Department of Cardiology, J. N. Medical college, Belgaum, Karnataka, India590001 